\title{
CONSTITUTIONAL STATUS OF NATIONAL MINORITIES IN ROMANIA
}

Eugen Chelaru, University of Pitești, Prof. PhD hab., Faculty of Economic Sciences and Law, Bld. Republicii, no. 71, Pitesti, Romania chelaru.eugen@gmail.com

Andra Puran, University of Pitești, Lecturer, PhD, Faculty of Economic Sciences and Law, Bld. Republicii, no. 71, Pitesti, Romania https://orcid.org/0000-0002-8773-1548

*andradascalu@yahoo.com

\begin{abstract}
There is no purely ethnic state in Europe, so the constitutional regulation of the tatus of minorities is a necessity. The Constitution of Romania, within the general principles of the constitutional system, regulates the right to preserve, develop and express the ethnic, cultural, linguistic and religious identity of national minorities. These regulations set out the framework within which other constitutional provisions relating to the status of such persons and the general limits imposed to the legislator in defining it, should be laid down.
\end{abstract}

Keywords: national minority, ethnicity, migration, identity, electoral rights.

\section{INTRODUCTION}

Like most other European states, Romania was born at a time when the idea of a national state had not yet prevailed in public international law. Although the Romanian ethnic groups have always been the majority, historical circumstances have generated changes in the population structure, including through territorial changes, which have led to the emergence of a significant mass of people belonging to other ethnic groups, with whom they lived. The need to protect the identity of minorities and the recognition of specific rights leading to this result was a long process, influenced by historical events and the evolution of political ideas.

The Romanian state was founded on January 24, 1859, as a result of the union of the principalities of Wallachia and Moldavia, under the name of the United Principalities of Moldavia and Wallachia, which included less than half of the territories inhabited by Romanians, but also a large number of minorities, especially Jews. The first Constitution of Romania, adopted in 1866, made no reference to citizens belonging to national minorities (Iancu, 2014). In fact, the authorities did not even use the term "minorities", the inhabitants of Romania being divided into two main categories: Romanians and foreigners. Foreigners also formed two categories - those who were "foreign subjects", i.e. those who had the 
citizenship of a foreign state and those without any citizenship.

The end of the First World War, which fundamentally changed not only the political architecture of Europe, but also the conceptions about the status of minorities, brought great changes in Romania, a state in the camp of the victors. Thus, the year 1918 is marked by the process of union with Romania of most of the territories inhabited by Romanians: Bessarabia (territory occupied by Russia), Bukovina, Banat, Crișana, Maramureș and Transylvania (territories occupied by the Austro-Hungarian Empire, which disintegrates). Although the Romanians were the majority in all these historical provinces, they were accompanied by a large number of people belonging to other ethnic groups, especially Hungarians, Germans, Ukrainians, Russians and Jews (Bălan, 2018). Such a change in ethnic composition was foreseeable, so at the Paris Peace Conference (1919-1920), the "Treaty concluded between the Main Allied Powers and Romania on the protection of minorities and trade relations" was negotiated and signed (Bălan, 2018).

In 1923 a new Constitution was adopted, which also attaches great importance to the rights of national minorities. National minorities were represented in Parliament and participated in the debate on the draft of the new Constitution, which will proclaim equality before the law of all Romanian citizens will provide that the distinction between religious beliefs and denominations, of ethnic origin and language, acquire civil and political rights and exercise them. However, the rights belonging to citizens who were part of national minorities were enshrined mainly in "fundamental" (organic) laws. For example, in electoral matters, the law gave some privileges to national minorities in terms of how to assign seats, so as to ensure their representation in Parliament, and religious cults recognized by the state were legally represented in the Senate (Ionescu, 2018).

Even if after the Second World War the structure of the population in Romania changed, especially as a result of the occupation by the Soviet Union of Bessarabia and northern Bukovina, the Constitutions adopted by the communist power in 1948, 1952 and 1965 also contained provisions proclaiming equality in rights with Romanians of citizens belonging to national minorities.

According to the 2011 census, the population of Romania was 20.121 .641 people, of which 88,9 \% Romanians, 6,5 \% Hungarians, 3,3 \% Roma (Gypsies). Ethnic groups larger than 20,000 people registered only Ukrainians, Germans, Turks, Russians and Lipovans, Tatars.

\section{PURPOSE, MATERIALS AND METHODS}

The present study aims to analyze in general terms the constitutional status of national minorities in Romania. All Romanian citizens have fundamental rights provided by the Constitution and which are based on international regulations. In addition to these rights, national minorities also enjoy specific fundamental rights.

To achieve this goal, several methods of scientific research are combined, respectively: the logical method, the comparative method, the historical method, as well as the study of documents, the paper falling within the scope of constitutional law. The study has an interdisciplinary character considering the sources of documentation belonging to various fields: constitutional law, international law, general theory of law. The realization of the paper was based on the traditional bibliographic documentation, but also on the direct 
documentation through the analysis of the international and constitutional dispositions in the field.

\section{The notion of national minority}

There is no unanimously accepted definition of national minorities in international law. The most important attempts to define this notion were made under the auspices of the United Nations, commissioning three studies, conducted by F. Capotorti in 1971, J. Deschenes in 1984 and M. Corbo in 1986. The definition given by F. Capotorti it is the starting point for other definitions given at the doctrinal level and is based on numerical and sociological criteria. Capotorti defined the minority as "a group numerically inferior to the rest of the population of a state, in a non-dominant position, whose members, being citizens of the state, possess ethnic, religious or linguistic characteristics that differ from those of the rest of the population and show, even if only implicitly, a spirit of solidarity, in order to preserve their culture, traditions, religion or language" (Lajoie, 2002).

The definition developed by M. J. Deschenes (Selejan-Guțan, 2008) evokes the same essential elements, based on an objective and a subjective criterion. The objective criterion takes into account the numerical inferiority, the non-dominant character of the group, distinct characteristics regarding ethnicity, religion or language and the existence of a sufficiently large number to preserve the characteristics. From a subjective point of view, the desire to keep the specific characteristics, solidarity but also the feeling of belonging to that group are taken into account.

The most important European attempts to define national minorities are identified in the Recommendation 1134 of the Parliamentary Assembly of the Council of Europe on the rights of persons belonging to national minorities, adopted on October 10, 1990 and in Recommendation 1201 of the Parliamentary Assembly of the Council of Europe of February 01, 1993. According to point 11 of Recommendation 1134, national minorities are "separate or distinct groups, well defined and established on the territory of a state, the members of which are nationals of that state and have certain religious, linguistic, cultural or other characteristics which distinguish them from the majority of the population". Recommendation 1201 of the Parliamentary Assembly of the Council of Europe on February 01, 1993 considers those who: a) reside on the territory of a state and are its citizens; b) maintain long-term, lasting and permanent ties with that State; c) display distinct ethnic, cultural, religious or linguistic characteristics; d) are sufficiently representative, even if they are smaller than the rest of the population of a state or a region of that state; e) are motivated by the concern to keep together what constitutes their common identity, including their culture, traditions, religion or their language (Duminică\&Aleca, 2010).

These definitions have been criticized for either covering only one of the meanings given to the notion of national minority, in the sense that they refer only to minorities made up of nationals of the state in which the group has acquired the status of "ethnic minority" (Prisacariu, 2010), or a definition should start from the sociological to the political criterion (Dănișor, 2003).

The recent migrations, especially to Western countries, generate complex ethnocultural, linguistic, religious, economic and political differences, which gives legitimacy to the question 
of whether the status of "national minority" should not be granted to "new minorities" of immigrants, even if they do not "maintain long-term ties" with that state, have not acquired citizenship or the right of permanent residence and do not meet all the other criteria to be considered a "national minority".

Romanian legislation does not define the analyzed notion, but in the Treaty of Friendship, Cooperation and Good Neighborhood with Hungary (1996), as well as in the Treaty on Cooperation and Good Neighborhood Relations between Romania and Ukraine (1997), reference is made to Recommendation 1201 of the Parliamentary Assembly of the Council of Europe of February 01, 1993. The treaties being ratified by the Parliament, it can be said that, based on Art 11 of the Romanian Constitution, the definition contained in this Recommendation has acquired normative value internally.

\section{Subjects of law benefiting from the status conferred on national minorities}

Who benefits from the rights granted to national minorities - the people who belong to these communities or the ethnic groups to which they belong?

We believe that the answer must be nuanced.

On the one hand, not every ethnic group that is different from the majority population can be qualified as a national minority, but only the one whose existence is recognized by law. On the one hand, once the existence of the national minority is recognized, the question arises on determining the natural persons who form it, because only they can hold certain rights. Recommendation 1134 refers to "the rights of persons belonging to national minorities" and not to "the rights of national minorities".

Two criteria can be used to determine a person's membership in a minority - the objective criterion, based on distinct ethnic, cultural, religious or linguistic characteristics, and the subjective criterion, based on the person's will to belong to that minority. The Romanian Constitution favors the subjective option, stating that discriminatory legal treatments or legal privileges should not be created for persons depending on the sociological criteria that place them in a minority, while stating the need to preserve the identity of these persons without necessarily placing them in a minority. based on their will (Dănișor, 2010).

The recognition of special rights is therefore addressed to citizens viewed individually, and not to groups of citizens, and cannot lead to territorial autonomy on ethnic grounds. The number of members forming a certain national minority can only be a criterion according to which a right may or may not be granted.

The Constitutional Court had the opportunity to rule on such an issue by Decision No. 80/2014 (published in the Official Gazette of Romania, Part I, No. 246/7 April 2014), when it examined a legislative proposal to revise the Constitution. According to this proposal, Art 3 is supplemented by Para $3^{1}$, according to which "Traditional areas may recognize traditional areas as administrative subdivisions of regions". It was declared unconstitutional, the Court invoking several arguments.

The inaccuracy of the tradition criterion, which was proposed for the recognition of the new administrative-territorial units, was noted and it was found that it is not specified what relations would be established between the new administrative subdivisions and the existing administrative-territorial units. The Court also noted that the proposed text "induces the 
idea of territorial autonomy of some population groups" only on the basis of the identity of traditions, which "affects the administrative organization, economy, taxation, through the possibility of autonomous bodies to enact mandatory rules for members community". In this way, the unitary character of the Romanian state is affected, an aspect that cannot be the object of a revision of the Constitution, according to Art 152, Para 1.

\section{The main rights specific to national minorities regulated by the Romanian Constitution}

The Romanian Constitution (adopted in 1991 and revised in 2003) uses the phrase "national minorities", although during the debates of the Constituent Assembly on the draft constitution the issue of using the phrase "ethnic minorities" was raised. However, it was objected that "ethnicity expresses a predominantly biological relationship, while belonging to a national minority expresses something more, a social-political, cultural, spiritual relationship, and so on. The national minority is therefore a proximate gender category, while the ethnic minority is a specific difference, absorbed in the proximate gender of the national minority" (Deleanu, 1998).

Like the relevant international regulations, the Romanian Constitution regulates the status of national minorities, enshrining the individual rights of persons belonging to these minorities.

\subsection{The right to identity}

The provisions of Art 6 of the Romanian Constitution regulates the right to ethnic, cultural, linguistic and religious identity of persons belonging to national minorities, in conditions that do not discriminate against other Romanian citizens. These constitutional provisions constitute the common law on the protection of persons belonging to national minorities, outlining the general framework within which the legal provisions determining their status must be situated.

The Constitutional Court referred to the principles of equality and non-discrimination in relation to other Romanian citizens by Decision No 80/2014, cited above. It was proposed that two new paragraphs be added to Art 6 of the Constitution, according to which the legal representatives of national minorities were empowered to set up their own decisionmaking and executive bodies, with competences on the right to preserve, develop and express their identity and central public authorities. and local organizations were obliged to consult national minority citizens' organizations before making decisions on the preservation, development and expression of their ethnic, cultural, linguistic and religious identity.

The Court found that the first paragraph contravenes Art 1 of the Constitution, which enshrines the unitary character of the Romanian state, because the essence of such a state "is the existence of a unique set of institutions with political decision-making power". The creation of its own decision-making and executive bodies would have the consequence of achieving a collective political autonomy based on ethnic criteria. At the same time, privileges would be granted to national minorities, which is contrary to Art 6 Para 2 of the Constitution. 
Regarding the obligation of central and local public authorities to consult the organizations of citizens belonging to national minorities in matters concerning them, the Court recalled that regulating the ways in which the state guarantees the right to identity of national minorities is not within the scope of the Constitution but of the law (Constitutional Court, Decision No 799/2011, published in the Official Gazette of Romania, Part I, No 440/23 June 2011) that this contradicts "the principles of equality and non-discrimination against other Romanian citizens".

The constitutional right to identity has as its object different forms of identity: ethnic, cultural, linguistic and religious.

3.1.1. Ethnic identity is a difficult concept to define given that the features of the ethnic group aim at the use by its members of a distinct language or a common culture, different from that of the majority of the population. However, both cultural and linguistic identity are guaranteed separately from constitutional norms. In this context, it was shown that "ethnic traits are evolutionary, aspects of identity erected in ethnic traits depending on the type of opposition perceived by group members as essential at a given historical moment and in a particular conjuncture ... being forbidden to both the legislator and the Constitutional Court to use general definitions of the content of this right, which would limit in an abstract and general way the ethnic identity to certain particular features" (Dănișor, 2009).

The right to identity is exercised and is protected in conditions of equality and nondiscrimination against other Romanian citizens. Both the ethnic groups and the majority citizens, as well as the ethnic groups between them, are situated on an equal footing, being implicitly forbidden a hierarchy of ethnicities.

Ethnic identity is not an internal matter of the group but it delimits the members of the group from the other groups, assuming the right to identify as belonging to an ethnic group through features that the group considers defining for its identity.

3.1.2. Cultural identity as part of minority identity, implies the right to preserve the beliefs, customs, traditions, specific creations that belong to the spiritual heritage of the minority, but also the right to create cultural associations that promote and preserve cultural traditions.

Internationally, the term "culture" is defined as "values, beliefs, beliefs, languages, knowledge and arts, traditions, institutions and ways of life through which a person or group expresses its humanity and the meanings it gives to existence and development", while cultural identity is defined as" a set of cultural references by which a person, alone or in common, defines, constitutes, communicates and understands to be recognized in his dignity" (Art 2 Let a)-b) of the Fribourg Declaration on Cultural Rights, 2007).

In the Romanian doctrine it is considered that the constitutional regulation of Art 6 regarding cultural identity is interpreted "in the sense that the universality of cultural values, as general human values, must be expressed through diversity, just as diversity must be put at the service of universality, of general human values" (Dănișor, 2010).

3.1.3. Linguistic identity of persons belonging to national minorities is recognized in order to guarantee their right to preserve their identity through language and not to create linguistic diversity within the state. Moreover, the Romanian Constitution expressly provides that the official language is Romanian (Art 13). The right to linguistic identity 
is an individual right that implies the free use of languages in the private sphere, except in situations expressly provided for by constitutional rules, situations in which minority languages may be used in relations with local administrations or in justice.

3.1.4. Religious identity is constitutionally guaranteed to all persons by regulating the fundamental right to freedom of conscience (Art 29 of the Romanian Constitution). Often, however, a particular religion is practiced especially by members of an ethnic community.

Freedom of religion, as part of freedom of conscience, involves both the externalization of a faith, religion, and the freedom to adhere to a religious organization and ritual practiced. It is necessary that the religion or religious organization be recognized by law and the activity of a certain religious cult is not considered as contrary to the rule of law or good morals (Andreescu\&Puran, 2018). Religious cults are autonomous from the state and are organized according to their own statutes, in accordance with the law. It was decided that the autonomous existence of religious communities is indispensable in a democratic society and is an essential issue in the protection of religious freedom (Constitutional Court Decision No 448/2011, published in the Official Gazette of Romania, Part I, No 424/17 June 2011).

Freedom of conscience also implies the freedom to belong or not to any religion, which is why the Constitutional Court has ruled that the legislator has an obligation of neutrality and impartiality. This obligation is fulfilled in the situation where the state ensures the observance of these freedoms, consecrating, among others, the possibility of parents, legal representatives of minor students and, respectively, the possibility of adult students to request participation in religious classes (Constitutional Court Decision No 669/2014, published in the Official Gazette of Romania, Part I, No 59/23 January 2015).

\subsection{The right to learn and use one's mother tongue}

The right of persons belonging to minorities to learn and use their own language is closely related to the right to linguistic identity and cultural identity and is regulated in several constitutional provisions: Art 32 Para 3 (right to education), Art 120 (basic principles of local public administration) and Art 128 Para 2-3 (use of mother tongue and interpreter in court).

The organization and development of education must be done in the official language of the state, in the case of Romania the Romanian language, but the Constitution guarantees the right of persons belonging to national minorities to learn in their mother tongue and the right to be trained in this language. In order to guarantee the right to education in the mother tongue, a special body has been created within the Romanian Government - the Minorities Directorate, which "coordinates the implementation of the development and reform strategy in education for national minorities and aims at continuously aligning the quality of education for minorities. to the performance standards of the countries of the European Union". The Romanian state has also developed a Methodology on the study of the mother tongue and mother tongue and literature, of the Romanian language and literature, the study of the history and traditions of national minorities and of music education in the mother tongue, as a legal instrument guaranteeing the fundamental right. to education in the mother tongue. 
The 2003 constitutional revision granted, through Para 2 of Art 120, the possibility of using the languages of national minorities in relation to local public administration authorities, thus extending the use of these languages in public life. The quoted text stipulates that "in the administrative-territorial units in which the citizens belonging to a national minority have a significant share, the use of the language of the respective national minority is ensured in writing and orally in the relations with the local public administration authorities and with the deconcentrated public services under the conditions provided by the organic law". These constitutional provisions have been intensely criticized in the literature, considering that they violate the constitutional provisions of Art 4 which enshrines the unity of the people, prohibiting collective rights and the provisions of Art 13 which enshrines the Romanian language as an official language (Gîrleșteanu, 2010).

The special legislation (Law 215/2001 on local public administration, republished in the Official Gazette of Romania, Part I, No 123/20 February 2007) stipulates that public administration institutions can only use the Romanian language and official documents are written only in the official language, i.e. in Romanian, but also regulate the conditions and ways in which the languages of national minorities can be used. Thus, the use of mother tongues in relations with the public administration is allowed if the speakers of a minority language exceed the limit of $20 \%$ at the level of the administrative-territorial unit, the citizens being able to address and receive answers (both orally and in writing) in that language; this language may be used during meetings, hearings or other debates in the local Council, provided that the number of councilors belonging to a national minority represents at least one fifth of the total number of councilors, the decisions thus being taken being communicated in the minority language; local normative acts can be translated into the minority language and individual acts are communicated, upon request, in the mother tongue; the names of some institutions or localities, as well as the announcements of public interest are also inscribed in the mother tongue; certain public or private ceremonial events (for example, the marriage ceremony) may take place in the minority language (Prisacariu, 2010).

Also, the Romanian Constitution provides in Art 128 the possibility of using the mother tongue in court, while establishing limits to this right. The modalities for exercising the right to use the mother tongue, including through the use of interpreters or translations, shall be established in such a way as not to impede the proper administration of justice and not to involve additional costs for those concerned.

The doctrine considered the constitutional regulation analyzed to be excessive, showing that no fundamental law in European countries contains such a provision and, moreover, the European Convention on Human Rights and the International Covenant on Civil and Political Rights do not contain provisions on in the language used before the courts, but establishes only the obligation to provide a free interpreter, if necessary, especially in criminal matters.

\subsection{The specifics of electoral rights}

Regarding the electoral rights, Art 62 Para 2 of the Romanian Constitution provides that “citizens' organizations belonging to national minorities, which do not meet in elections the number of votes to be represented in Parliament, have the right to one seat each, under the 
conditions of the electoral law. Citizens of a national minority can only be represented by one organization". This regulates the way in which Romanian citizens belonging to national minorities participate in the exercise of state power through a representative body.

The Constitution does not limit the electoral rights of citizens belonging to national minorities in relation to those of majority citizens, but, on the contrary, provides a privilege if the organizations of citizens belonging to national minorities do not meet in the elections the number of votes to be represented in Parliament. Thus, acquiring a seat in the Chamber of Deputies, if they obtained, throughout the country, a number of votes equal to at least $5 \%$ of the average number of valid votes cast in the country for the election of a deputy.

The implementation of these constitutional provisions led to the establishment in the Chamber of Deputies of a parliamentary group consisting of 18 representatives of national minority organizations currently operating in Romania.

\section{CONCLUSIONS}

The citizens who have the distinctive features able to place the group they form in the category of national minority are a component part of the Romanian nation. The Constitution regulates and guarantees fundamental rights whose beneficiaries are all Romanian citizens, without offering privileges to Romanian ethnics. However, there is no denying that, although they do not have a dominant status, Romanians feel much more comfortable than minorities in a state that bears the name of the people of which they are part and whose official language is Romanian. Even if we take into account only these aspects, we can understand why it is necessary for persons belonging to national minorities to be granted additional rights, meant to guarantee their preservation of identity and assertion in public life, even if it leads to positive discrimination in relationship with the majority.

At the same time, the Constitution grants these additional rights to individuals, and not to certain communities. They benefit equally the people who live in compact groups, which may be the majority in some parts of Romania, and those who are dissipated in the large mass of the population. In order to avoid any confusion, it would be more appropriate to speak consistently about the rights of persons belonging to national minorities, and not about the rights of national minorities, although the latter expression is more concise.

The resurgence of the demands made by some groups of minority citizens in different states, which invoke the Kosovo precedent and claim either independence or ethnic autonomy, proves how difficult it is to maintain the balance between the unity and indivisibility of states, on the one hand, and the content and extent of the rights that can be granted to persons belonging to national minorities, on the other hand. Maintaining this balance is difficult especially when the current minorities were part of a dominant nation in a certain historical period, as is the case of Hungarians living in Romania and who show a tendency to enclave.

However, we appreciate that the provisions of the Romanian Constitution, developed through a well-articulated special legislation, are able to ensure this balance, if they are interpreted and applied in good faith, both by the authorities and by the beneficiaries. 


\section{REFERENCES}

Andreescu, M., Puran A., (2018). Drept constituţional. Teoria generală şi instituţii constituţionale. Jurisprudență constituţională, $3^{\text {rd }}$ Edition, Bucharest: C. H. Beck.

Bălan, M. (2018). Considerații în legătură cu drepturile minorităților în România Mare. Dreptul, 11.

Dănișor, D. C. (2010). Dreptul la identitate al persoanelor aparținând minorităților naționale. In: Dreptul la identitate, Bucharest: Universul Juridic.

Dănișor, D. C. (2009). Constituția României comentată. Titlul I. Principii generale, Bucharest: Universul Juridic.

Dănișor, D. C. (2003). Noțiunea de minoritate: de la definirea sociologică către definirea politică, Revista de Drept public 2.

Dănișor, Gh. (2010). Identitatea culturală. In: Dreptul la identitate, Bucharest: Universul Juridic.

Deleanu, I. (1998). Geneza Constituției României 1991, Bucharest: Official Gazette Press.

Duminică, R., Aleca C. (2010). Brief Considerations on Defining Concept of National Minority, Agora International Journal of Juridical Sciences, 1.

Gîrleșteanu, G., (2010). Limba oficială, limbile minoritare și administrația publică. In: Dreptul la identitate, Bucharest: Universul Juridic.

Iancu, Gh. (2014). Drept constituţional și instituţii politice, $3^{\text {rd }}$ Edition. Bucharest: C. H. Beck.

Ionescu, C. (2018). Desăvârșirea unității statale și naționale a României - un proces istoric obiectiv.

Dreptul 12.

Muraru, I., Tănăsescu, E. S. (2008). Constituţia României. Comentariu pe articole, Bucharest: C. H. Beck.

Prisacariu, M. R. (2010). Statutul juridic al minorităților naționale, Bucharest: C. H. Beck.

https://www.edu.ro/DirectiaMinorități

https://droitsculturels.org 